\title{
Nonomuraea wenchangensis sp. nov., isolated from mangrove rhizosphere soil
}

\author{
Fan Wang, ${ }^{1,2}$ Xiao-Xiong Xu, ${ }^{1}$ Zhi Qu, ${ }^{1}$ Cheng Wang, ${ }^{1}$ Hai-Peng Lin, ${ }^{1}$ \\ Qing-Yi Xie, ${ }^{1} \mathrm{Ji}$-Sheng Ruan, ${ }^{1}$ Ming $\mathrm{Sun}^{2}$ and Kui Hong ${ }^{1}$
}

\author{
Correspondence \\ Kui Hong \\ k1022@163.net
}

\author{
${ }^{1}$ Laboratory of Tropical Microbial Resource, Hainan Province, Key Laboratory of Tropical Crop \\ Biotechnology, Ministry of Agriculture, Institute of Tropical Bioscience and Biotechnology, \\ Chinese Academy of Tropical Agriculture Sciences, Haikou 571101, PR China \\ ${ }^{2}$ College of Life Science and Technology, Huazhong Agricultural University, Wuhan 430000, \\ PR China
}

The genus Nonomuria, which was proposed by Zhang et al. (1998), belongs to the family Streptosporangiaceae, a member of the suborder Streptosporangineae within the order Actinomycetales. Chiba et al. (1999) subsequently corrected the spelling of the genus name to Nonomuraea. At the time of writing, this genus comprised 24 species with validly published names and two subspecies (Euzéby, 2010).

During the process of searching for actinomycetes that can produce commercially important secondary metabolites, a novel actinomycete, strain $210417^{\mathrm{T}}$ was isolated from a rhizosphere soil sample of the mangrove Bruguiera sexangula in Wenchang, Hainan, China. The strain produced metabolites that showed activity against the SMMC-7721 cancer cell line. The soil sample was heattreated at $100{ }^{\circ} \mathrm{C}$ for $1 \mathrm{~h}$ after being air-dried at room temperature for 7 days and treated with a solution of chloramine-T (1\%, w/v) (Hayakawa et al., 1997). The

Abbreviations: DAP, diaminopimelic acid; GlcNU, unknown glucosamine-containing phospholipid; ISP, International Streptomyces Project; $\mathrm{PE}$, phosphatidylethanolamine; PME, phosphatidylmethylethanolamine.

The GenBank/EMBL/DDBJ accession number for the 16S rRNA gene sequence of Nonomuraea wenchangensis $210417^{\top}$ is FJ261959.

A supplementary table is available with the online version of this paper. pretreated soil sample was diluted $1: 10(\mathrm{v} / \mathrm{v})$ with sterile $1 /$ 4 Ringer's solution $\left(\mathrm{K}_{2} \mathrm{HPO}_{4}, 0.38 \% ; \mathrm{KH}_{2} \mathrm{PO}_{4}, 0.12 \%\right.$; $\mathrm{MgSO}_{4} .7 \mathrm{H}_{2} \mathrm{O}, 0.51 \% ; \mathrm{NaCl}, 0.25 \% ; \mathrm{Fe}_{2}\left(\mathrm{SO}_{4}\right)_{3} .7 \mathrm{H}_{2} \mathrm{O}$, $\left.0.005 \% ; \mathrm{MnSO}_{4}, 0.005 \%\right)$ and serial dilutions were prepared down to $10^{-3}$. One hundred microlitres of the $10^{-1}$ to $10^{-3}$ suspensions were spread, in triplicate, on glucose-aspartic acid-vitamin medium (Hayakawa et al., 1991) supplemented with cycloheximide $\left(50 \mathrm{mg} \mathrm{l}^{-1}\right)$, nystatin $\left(50 \mathrm{mg} \mathrm{l}^{-1}\right)$ and nalidixic acid $\left(50 \mathrm{mg} \mathrm{l}^{-1}\right)$. After 21 days of aerobic incubation at $28{ }^{\circ} \mathrm{C}$, the strain was purified and maintained as a working culture on yeast extract-malt extract agar [International Streptomyces Project (ISP) medium 2; Shirling \& Gottlieb, 1966]. The aim of this study was to determine the taxonomic position of isolate $210417^{\mathrm{T}}$ using a polyphasic approach. For comparative purposes, Nonomuraea coxensis JCM $13931^{\mathrm{T}}$ and Nonomuraea bangladeshensis JCM $13930^{\mathrm{T}}$ were used as reference strains in this study.

Genomic DNA extraction, PCR amplification of the $16 \mathrm{~S}$ rRNA gene and sequencing of the PCR products were carried out as described by Hong et al. (2009). The almostcomplete 16S rRNA gene sequence of strain $210417^{\mathrm{T}}$ (1484 nt) was aligned with nucleotide sequences obtained from GenBank/EMBL/DDBJ using CLUSTAL x software 
(Thompson et al., 1997). A phylogenetic tree was reconstructed using the neighbour-joining (Saitou \& Nei, 1987) and maximum-parsimony (Fitch, 1971) methods from the software package MEGA version 3.1 (Kumar et al., 2004). Confidence in tree topology was evaluated by using bootstrap analysis (Felsenstein, 1985) based on 1000 resamplings. Sequence similarity values between strain $210417^{\mathrm{T}}$ and related species were calculated using EzTaxon (http://www.eztaxon.org/; Chun et al., 2007).

Cell morphology was observed by light microscopy (80i, Nikon) and scanning electron microscopy (FEI QUANTA) of cultures grown for 21 days at $28{ }^{\circ} \mathrm{C}$ on oatmeal agar (ISP 3). Cultural characteristics were determined by the methods proposed by Shirling \& Gottlieb (1966) after 3 weeks at $28{ }^{\circ} \mathrm{C}$. ISCC-NBS colour charts (Kelly, 1964) were used to determine the colours of substrate and aerial mycelia. Growth at various temperatures $\left(4-45{ }^{\circ} \mathrm{C}\right)$ was determined on ISP 2 for 14-21 days. $\mathrm{NaCl}$ tolerance and the $\mathrm{pH}$ range for growth were determined in cells grown in $0-8 \% \mathrm{NaCl}$ and at $\mathrm{pH} 4-12$, respectively, on ISP 2 at $28{ }^{\circ} \mathrm{C}$ for 14-21 days. The ability to use carbohydrates as sole carbon sources was tested according to the methods of Gordon et al. (1974). Decomposition of casein (skimmed milk), gelatin, hypoxanthine, tyrosine and xanthine was assessed following the procedures described by Williams et al. (1983).

For chemotaxonomic analysis, biomass was obtained from ISP 2 broth after incubation at $28{ }^{\circ} \mathrm{C}$ for $5-7$ days in shake flasks (200 r.p.m.). The isomeric form of diaminopimelic acid (DAP) and sugars in whole-cell hydrolysates were determined based on standard procedures, as described previously (Hasegawa et al. 1983; Lechevalier \& Lechevalier, 1980). The $N$-acyl type of muramic acid in the peptidoglycan was analysed according to the method of Uchida \& Aida (1984). Menaquinones were extracted from freeze-dried cells and purified according to Minnikin et al. (1984); composition was determined by HPLC using an ODS-BP C18 column $(4.6 \times 250 \mathrm{~mm})$. Fatty acids were extracted by the method of Sasser (1990) and analysed by GC (Oliver \& Colwell, 1973). Phospholipid analysis was carried out by TLC according to Minnikin et al. (1984).

Genomic DNA for DNA-DNA hybridization was extracted using a $\mathrm{CTAB}$ method, as described by Wang \& Hong (2010). The DNA G + C content was determined by HPLC (Mesbah et al., 1989). Levels of DNA-DNA relatedness were measured on nylon membranes using the method described by Wang et al. (2011).

Strain $210417^{\mathrm{T}}$ exhibited white aerial mycelium on ISP 2, ISP 3, ISP 5, modified Bennett's agar (Jones, 1949) and glucose-yeast extract media. Good growth occurred on ISP 2, ISP 6, ISP 7 and glucose-yeast extract agar media; moderate growth was observed on ISP 1, ISP 3, nutrient agar and modified Bennett's agar media; and poor growth was seen on ISP 5 medium. No diffusible pigment was detected on any media tested. After approximately 14 days, strain $210417^{\mathrm{T}}$ showed morphological characteristics that are typical of the genus Nonomuraea, i.e. the formation of extensively branched aerial and substrate mycelia and spiral spore chains borne on the aerial mycelium. The spore chains of strain $210417^{\mathrm{T}}$ were covered with rough sheaths (Fig. 1), which are similar to those of $N$. bangladeshensis JCM $13930^{\mathrm{T}}$ but different from those of $N$. coxensis JCM $13931^{\mathrm{T}}$. In addition, the sheaths of $N$. bangladeshensis JCM $13930^{\mathrm{T}}$ were smooth, whereas those of strain $210417^{\mathrm{T}}$ were rough (Fig. 1). The physiological and biochemical characteristics of strain $210417^{\mathrm{T}}$ are given in Table 1 and the species description.

Chemotaxonomic characteristics support the classification of strain $210417^{\mathrm{T}}$ as a member of the genus Nonomuraea. Whole-cell hydrolysates yielded madurose as the diagnostic sugar. The cell-wall peptidoglycan contained meso-DAP and $\mathrm{N}$-acetylmuramic acid (cell-wall chemotype III B; Lechevalier \& Lechevalier, 1970). The predominant menaquinone was MK-9 $\left(\mathrm{H}_{4}\right)(83 \%)$. Small amounts of MK-9 $\left(\mathrm{H}_{6}\right)(10 \%)$, MK-9 $\left(\mathrm{H}_{2}\right)(5 \%)$ and MK-9 $\left(\mathrm{H}_{0}\right)(2 \%)$ were also detected. Large amounts of iso- $\mathrm{C}_{16: 0}(24.1 \%)$ in combination with $\mathrm{C}_{17: 0}(12.5 \%)$, 10-methyl $\mathrm{C}_{18: 0}$ (TBSA; $\left.12.3 \%\right)$ and 10 methyl $\mathrm{C}_{17: 0}(7.1 \%)$ were present as major fatty acids; minor fatty acids were iso- $\mathrm{C}_{18: 0}(6.8 \%)$, iso- $\mathrm{C}_{15: 0}(5.7 \%)$, summed feature 3 (iso- $\mathrm{C}_{15: 0} 2-\mathrm{OH}$ and/or $\left.\mathrm{C}_{16: 1} \omega 7 c\right)(5.0 \%)$ and $\mathrm{C}_{15: 0}(3.6 \%)$ (Supplementary Table S1 available in IJSEM Online). The diagnostic phospholipid phosphatidylethanolamine (PE), phosphatidylmethylethanolamine (PME) and an unknown glucosamine-containing phospholipid (GlcNU) were detected (phospholipid type IV; Lechevalier et al., 1977). The DNA G +C content was $72 \mathrm{~mol} \%$.

The almost-complete $16 \mathrm{~S}$ rRNA gene sequence (1484 nt) of isolate $210417^{\mathrm{T}}$ was compared with sequences of representatives of the genus Nonomuraea. Highest sequence similarities

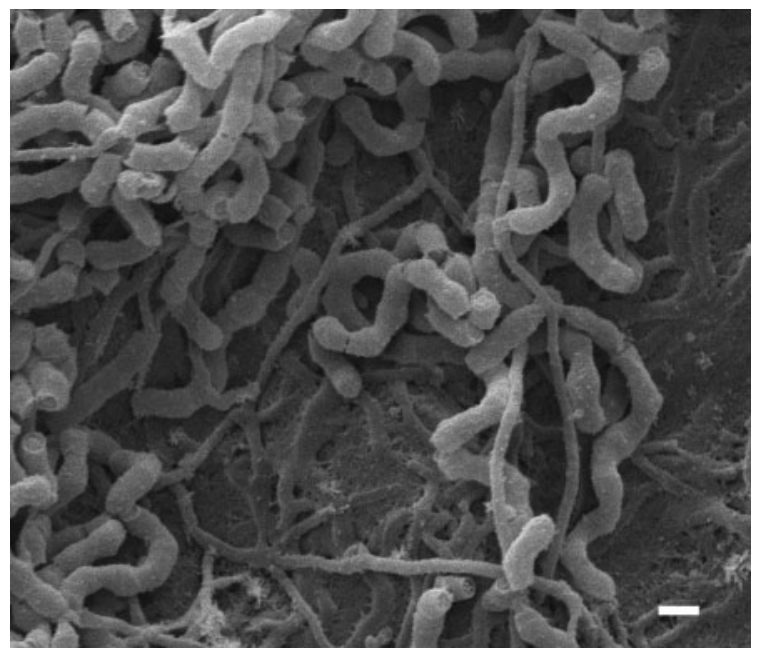

Fig. 1. Scanning electron micrograph of spiral spore chains on aerial mycelia of Nonomuraea wenchangensis strain $210417^{\top}$ grown on oatmeal agar (ISP 3 ) at $28^{\circ} \mathrm{C}$ for 21 days. Bar, $1 \mu \mathrm{m}$. 
Table 1. Comparison of the phenotypic properties of strain $210417^{\top}$ and phylogenetically most closely related species

Strains: $1,210417^{\mathrm{T}} ; 2$, N. coxensis JCM $13931^{\mathrm{T}} ; 3$ N. bangladeshensis JCM $13930^{\mathrm{T}}$. +, Positive; -, negative; \pm , weakly positive. Data from this study except where marked.

\begin{tabular}{|c|c|c|c|}
\hline Characteristic & 1 & 2 & 3 \\
\hline \multicolumn{4}{|l|}{ Spore-chain morphology } \\
\hline Spore chain ${ }^{\star}$ & $S$ & Str, $\mathrm{H} \dagger$ & $\mathrm{S} \dagger$ \\
\hline Spore ornamentation & Rough & Smooth $\dagger$ & Smooth $\uparrow$ \\
\hline Number of spores & $6-10$ & $12-17 \dagger$ & $8-12 \dagger$ \\
\hline \multicolumn{4}{|c|}{ Growth on ISP 3 medium } \\
\hline Aerial mycelium & White & Pink to white $\dagger$ & Pale brown $\dagger$ \\
\hline Substrate mycelium & Pale pink & Orange $\dagger$ & Pale brown $\dagger$ \\
\hline Growth at $45{ }^{\circ} \mathrm{C}$ & - & $+\dagger$ & $+\dagger$ \\
\hline $\mathrm{pH}$ range for growth & $6-10$ & $5-9 \dagger$ & $5-9 \dagger$ \\
\hline Major menaquinone(s) & MK-9 $\left(\mathrm{H}_{4}\right)$, MK-9 $\left(\mathrm{H}_{6}\right)$ & MK-9 $\left(\mathrm{H}_{6}\right)$, MK- $9\left(\mathrm{H}_{4}\right) \dagger$ & MK- $9\left(\mathrm{H}_{4}\right) \dagger$ \\
\hline Nitrate reductase & + & + & - \\
\hline \multicolumn{4}{|l|}{ Degradation of: } \\
\hline Starch & - & + & + \\
\hline Tyrosine & + & - & + \\
\hline \multicolumn{4}{|l|}{ Production of: } \\
\hline Urease & + & + & - \\
\hline$\beta$-Galactosidase & + & - & - \\
\hline \multicolumn{4}{|l|}{ Utilization of: } \\
\hline L-Arabinose & + & - & - \\
\hline Sucrose & + & + & \pm \\
\hline D-Xylose & + & - & - \\
\hline myo-Inositol & + & - & - \\
\hline D-Mannose & - & + & + \\
\hline D-Fructose & + & - & - \\
\hline L-Rhamnose & + & + & + \\
\hline Raffinose & + & - & - \\
\hline Cellobiose & - & \pm & - \\
\hline
\end{tabular}

${ }^{\star} \mathrm{H}$, Hooks, curled; S, spirals of one or two turns; Str, straight.

$\dagger$ Data from Ara et al. (2007).

were shown to the type strains of $N$. coxensis (99.6\%) and $N$. bangladeshensis (99.3\%). A neighbour-joining phylogenetic tree based on 16S rRNA gene sequences indicated that strain $210417^{\mathrm{T}}$ formed a monophyletic clade with $N$. coxensis JCM $13931^{\mathrm{T}}$ and N. bangladeshensis JCM $13930^{\mathrm{T}}$ (Fig. 2).

It has been reported that Nonomuraea species have high 16S rRNA gene sequence similarities (97.6-99.4\%), but low DNA-DNA relatedness values (Fischer et al., 1983; Poschner et al., 1985; Tamura et al., 2000; Kämpfer et al., 2005; Qin et al., 2009). The type strains of Nonomuraea africana, Nonomuraea dietziae and Nonomuraea recticatena shared high 16S rRNA gene sequence similarities (within the range 98.9-99.8\%), whereas the highest DNA-DNA relatedness values between them have been reported as 45$48 \%$ (Stackebrandt et al., 2001). For these reasons, DNADNA hybridizations were only carried out between strain $210417^{\mathrm{T}}, N$. coxensis JCM $13931^{\mathrm{T}}$ and $N$. bangladeshensis JCM $13930^{\mathrm{T}}$. Mean DNA-DNA hybridization values of $56.5 \pm 2.3 \%$ and $36.9 \pm 1.9 \%$ were observed for strain $210417^{\mathrm{T}}$ with $N$. coxensis JCM $13931^{\mathrm{T}}$ and $N$. bangladeshensis JCM $13930^{\mathrm{T}}$, respectively. These values are signifi- cantly lower than the $70 \%$ threshold for species delineation as recommended by Wayne et al. (1987).

Strain $210417^{\mathrm{T}}$ can be distinguished from N. coxensis JCM $13931^{\mathrm{T}}$ and $N$. bangladeshensis JCM $13930^{\mathrm{T}}$ based on spore surface ornamentation, growth characteristics on ISP 3 medium (the colour of aerial and substrate mycelium), physiological and biochemical reactions (nitrate reduction, some degradation tests and carbon utilization), major menaquinones (Table 1) and fatty acid composition (Supplementary Table S1). Both phenotypic and genotypic data show that strain $210417^{\mathrm{T}}$ differs from previously described species of the genus Nonomuraea. It is therefore proposed that strain $210417^{\mathrm{T}}$ represents a novel species within the genus Nonomuraea, Nonomuraea wenchangensis sp. nov.

\section{Description of Nonomuraea wenchangensis sp. nov.}

Nonomuraea wenchangensis (wen.chan.gen'sis. N.L. fem. adj. wenchangensis of or pertaining to Wenchang, from where the type strain was isolated). 


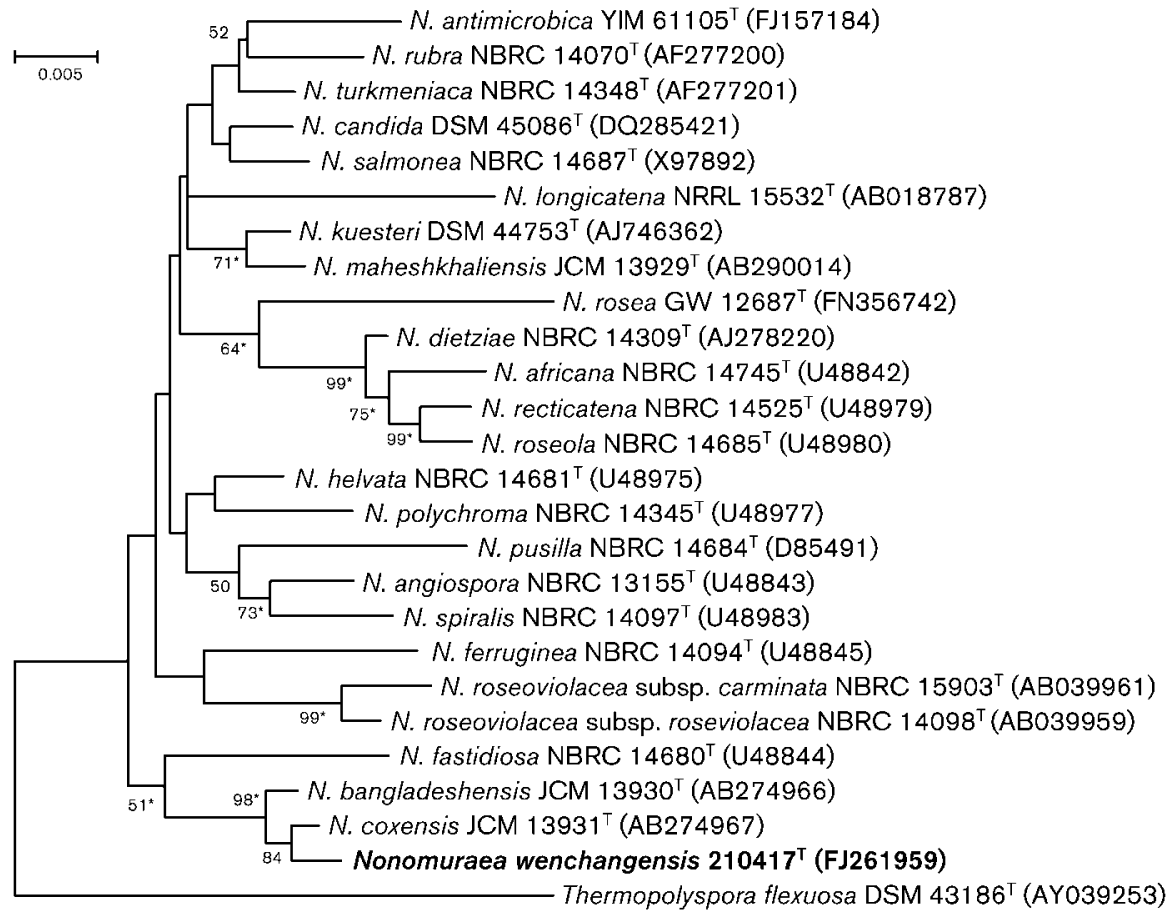

Fig. 2. Neighbour-joining tree based on nearly complete $16 \mathrm{~S}$ rRNA gene sequences (1484 nt) showing relationships between strain $210417^{\top}$ and all species of the genus Nonomuraea with validly published names. Thermopolyspora flexuosa DSM $43186^{\top}$ was used as an outgroup. Asterisks indicate branches that were also recovered using the maximum-parsimony (Fitch, 1971) tree-making algorithm. Bootstrap values are expressed as percentages of 1000 replications. Only bootstrap values of more than $50 \%$ are shown. Bar, 0.005 substitutions per site.

Aerobic, Gram-positive, non-acid-fast actinomycete that forms highly branched substrate and aerial mycelia. After approximately 14 days, the aerial mycelium produces spiral spore chains, each containing 6-10 spherical spores that are covered with a rough sheath. Sporangia are not detected. The colour of the substrate mycelium on various agar plates is pale pink to dark brown. White aerial mycelia are observed on ISP 2, ISP 3, ISP 5, modified Bennett's agar and glucose-yeast extract media. Diffusible pigments are not produced. Grows at $20-37^{\circ} \mathrm{C}$ and $\mathrm{pH} 6.0-10.0$, with optimal growth occurring at $28{ }^{\circ} \mathrm{C}$ and $\mathrm{pH}$ 7.2. Growth occurs in the presence of $0-4 \%(\mathrm{w} / \mathrm{v}) \mathrm{NaCl}$, but no growth is observed at $5 \%(\mathrm{w} / \mathrm{v}) \mathrm{NaCl}$. Degrades casein and tyrosine, but not hypoxanthine, starch, xanthine or gelatin. Positive for aesculin hydrolysis, nitrate reduction, urease, gelatinase, arginine dihydrolase and $\beta$-galactosidase production, but negative for citrate lyase, lysine decarboxylase, ornithine decarboxylase and acetoin production. LArabinose, sucrose, D-xylose, myo-inositol, D-fructose, Lrhamnose and raffinose are utilized as sole carbon sources, but not D-mannose or cellobiose. meso-DAP is the diagnostic diamino acid in the peptidoglycan. Whole cellhydrolysates contain madurose, galactose, glucose, mannose and ribose. The predominant menaquinone of the type strain is MK-9 $\left(\mathrm{H}_{4}\right)$; small amounts of MK- $9\left(\mathrm{H}_{6}\right)$, MK- $9\left(\mathrm{H}_{2}\right)$ and MK- $9\left(\mathrm{H}_{0}\right)$ are also detected. The major fatty acids are iso- $\mathrm{C}_{16: 0}, \mathrm{C}_{17: 0}, 10$-methyl $\mathrm{C}_{18: 0}$ (TBSA), 10methyl $\mathrm{C}_{17: 0}$, iso- $\mathrm{C}_{18: 0}$, iso- $\mathrm{C}_{15: 0}$, summed feature 3 (iso- $\mathrm{C}_{15: 0}$ 2-OH and/or $\mathrm{C}_{16: 1} \omega 7 c$ ) and $\mathrm{C}_{15: 0}$ (Supplementary Table S1). The polar lipids comprise PE, PME and GlcNU.

The type strain is $210417^{\mathrm{T}}\left(=\mathrm{CGMCC} 4.5598^{\mathrm{T}}=\mathrm{DSM}\right.$ $45477^{\mathrm{T}}$ ), isolated from mangrove rhizosphere soil collected from Wenchang, Hainan, China. The DNA G + C content of the type strain is $72 \mathrm{~mol} \%$.

\section{Acknowledgements}

This research was supported by grants from the National High Technology Research and Development Program of China (863 Program; no. 2007AA09Z415), the National Natural Science Foundation of China (no. U0633008) and a National Nonprofit Institute Research Grant (ITBBZD0753).

\section{References}

Ara, I., Kudo, T., Matsumoto, A., Takahashi, Y. \& Ōmura, S. (2007). Nonomuraea bangladeshensis sp. nov. and Nonomuraea coxensis sp. nov. Int J Syst Evol Microbiol 57, 1504-1509.

Chiba, S., Suzuki, M. \& Ando, K. (1999). Taxonomic re-evaluation of 'Nocardiopsis' sp. K-252 $2^{\mathrm{T}}$ (=NRRL $15532^{\mathrm{T}}$ ): a proposal to transfer this strain to the genus Nonomuraea as Nonomuraea longicatena sp. nov. Int J Syst Bacteriol 49, 1623-1630. 
Chun, J., Lee, J.-H., Jung, Y., Kim, M., Kim, S., Kim, B. K. \& Lim, Y. W. (2007). EzTaxon: a web-based tool for the identification of prokaryotes based on $16 \mathrm{~S}$ ribosomal RNA gene sequences. Int J Syst Evol Microbiol 57, 2259-2261.

Euzéby, J. (2010). List of prokaryotic names with standing in nomenclature. http://www.bacterio.cict.fr/index.html

Felsenstein, J. (1985). Confidence limits on phylogeny: an approach using the bootstrap. Evolution 39, 783-791.

Fischer, A., Kroppenstedt, R. M. \& Stackebrandt, E. (1983). Molecular-genetic and chemotaxonomic studies on Actinomadura and Nocardiopsis. J Gen Microbiol 129, 3433-3446.

Fitch, W. M. (1971). Toward defining the course of evolution: minimum change for a specific tree topology. Syst Zool 20, 406-416.

Gordon, R. E., Barnett, D. A., Handerhan, J. E. \& Pang, C. H.-N. (1974). Nocardia coeliaca, Nocardia autotrophica, and the nocardin strain. Int J Syst Bacteriol 24, 54-63.

Hasegawa, T., Takizawa, M. \& Tanida, S. (1983). A rapid analysis for chemical grouping of aerobic actinomycetes. J Gen Appl Microbiol 29, 319-322.

Hayakawa, M., Sadakata, T., Kajiura, T. \& Nonomura, H. (1991). New methods for the highly selective isolation of Micromonospora and Microbispora from soil. J Ferment Bioeng 72, 320-326.

Hayakawa, M., lino, H., Takeuchi, S. \& Yamazaki, T. (1997). Application of a method incorporating treatment with chloramine$\mathrm{T}$ for the selective isolation of Streptosporangiaceae from soil. J Ferment Bioeng 84, 599-602.

Hong, K., Gao, A. H., Xie, Q. Y., Gao, H., Zhuang, L., Lin, H. P., Yu, H. P., Li, J., Yao, X. S. \& other authors (2009). Actinomycetes for marine drug discovery isolated from mangrove soils and plants in China. Mar Drugs 7, 24-44.

Jones, K. L. (1949). Fresh isolates of actinomycetes in which the presence of sporogenous aerial mycelia is a fluctuating characteristic. J Bacteriol 57, 141-145.

Kämpfer, P., Kroppenstedt, R. M. \& Grün-Wollny, I. (2005). Nonomuraea kuesteri sp. nov. Int J Syst Evol Microbiol 55, 847-851.

Kelly, K. L. (1964). Color-name Charts Illustrated with Centroid Colors. Chicago: Inter-Society Color Council - National Bureau of Standards.

Kumar, S., Tamura, K. \& Nei, M. (2004). MEGA3: integrated software for molecular evolutionary genetics analysis and sequence alignment. Brief Bioinform 5, 150-163.

Lechevalier, M. P. \& Lechevalier, H. (1970). Chemical composition as a criterion in the classification of aerobic actinomycetes. Int J Syst Bacteriol 20, 435-443.

Lechevalier, M. P. \& Lechevalier, H. A. (1980). The chemotaxonomy of actinomycetes. In Actinomycete Taxonomy, pp. 22-291. Edited by A. Dietz \& D. W. Thayer. Arlington, VA: Society for Industrial Microbiology.

Lechevalier, M. P., De Bièvre, C. \& Lechevalier, H. A. (1977). Chemotaxonomy of aerobic actinomycetes: phospholipid composition. Biochem Syst Ecol 5, 249-260.

Mesbah, M., Premachandran, U. \& Whitman, W. B. (1989). Precise measurement of the $\mathrm{G}+\mathrm{C}$ content of deoxyribonucleic acid by highperformance liquid chromatography. Int J Syst Bacteriol 39, 159-167.
Minnikin, D. E., O'Donnell, A. G., Goodfellow, M., Alderson, G., Athalye, M., Schaal, A. \& Parlett, J. K. (1984). An integrated procedure for the extraction of bacterial isoprenoid quinones and polar lipids. J Microbiol Methods 2, 233-241.

Oliver, J. D. \& Colwell, R. R. (1973). Extractable lipids of gramnegative marine bacteria: fatty-acid composition. Int J Syst Bacteriol 23, 442-458.

Poschner, J., Kroppenstedt, R. M., Fischer, A. \& Stackebrandt, E. (1985). DNA-DNA reassociation and chemotaxonomic studies on Actinomadura, Microbispora, Microtetraspora, Micropolyspora and Nocardiopsis. Syst Appl Microbiol 6, 264-270.

Qin, S., Zhao, G.-Z., Klenk, H.-P., Li, J., Zhu, W.-Y., Xu, L.-H. \& Li, W.-J. (2009). Nonomuraea antimicrobica sp. nov., an endophytic actinomycete isolated from a leaf of Maytenus austroyunnanensis. Int J Syst Evol Microbiol 59, 2747-2751.

Saitou, N. \& Nei, M. (1987). The neighbor-joining method: a new method for reconstructing phylogenetic trees. Mol Biol Evol 4, 406425.

Sasser, M. (1990). Identification of bacteria by gas chromatography of cellular fatty acids, MIDI Technical Note 101. Newark, DE: Microbial ID.

Shirling, E. B. \& Gottlieb, D. (1966). Methods for characterization of Streptomyces species. Int J Syst Bacteriol 16, 313-340.

Stackebrandt, E., Wink, J., Steiner, U. \& Kroppenstedt, R. M. (2001). Nonomuraea dietzii sp. nov. Int J Syst Evol Microbiol 51, 1437-1441.

Tamura, T., Suzuki, S. \& Hatano, K. (2000). Acrocarpospora gen. nov., a new genus of the order Actinomycetales. Int J Syst Evol Microbiol 50, 1163-1171.

Thompson, J. D., Gibson, T. J., Plewniak, F., Jeanmougin, F. \& Higgins, D. G. (1997). The CLUSTAL_X windows interface: flexible strategies for multiple sequence alignment aided by quality analysis tools. Nucleic Acids Res 25, 4876-4882.

Uchida, K. \& Aida, K. (1984). An improved method for the glycolate test for simple identification of the acyl type of bacterial cell walls. $J$ Gen Appl Microbiol 30, 131-134.

Wang, F. \& Hong, K. (2010). CTAB method for genomic DNA extraction from Nonomuraea. Microbiology China 37, 1211-1215 (in Chinese).

Wang, C., Xu, X.-X., Qu, Z., Wang, H.-L., Lin, H.-P., Xie, Q.-Y., Ruan, J.-S. \& Hong, K. (2011). Micromonospora rhizosphaerae sp. nov., isolated from mangrove rhizosphere soil. Int J Syst Evol Microbiol 61, 320324.

Wayne, L. G., Brenner, D. J., Colwell, R. R., Grimont, P. A. D., Kandler, O., Krichevsky, M. I., Moore, L. H., Moore, W. E. C., Murray, R. G. E. \& other authors (1987). International Committee on Systematic Bacteriology. Report of the ad hoc committee on reconciliation of approaches to bacterial systematic. Int J Syst Bacteriol 37, 463-464.

Williams, S. T., Goodfellow, M., Alderson, G., Wellington, E. M. H., Sneath, P. H. A. \& Sackin, M. J. (1983). Numerical classification of Streptomyces and related genera. J Gen Microbiol 129, 1743-1813.

Zhang, Z. H., Wang, Y. \& Ruan, J. S. (1998). Reclassification of Thermomonospora and Microtetraspora. Int J Syst Bacteriol 48, 411422. 